\title{
Damping Off in Chilli and Its Biological Management-A Review
}

\author{
Misba Majeed ${ }^{1 *}$, G. Hassan Mir', Mudasir Hassan ${ }^{1}$, Fayaz A. Mohuiddin", \\ Shazia Paswal ${ }^{2}$ and Saima Farooq ${ }^{2}$ \\ ${ }^{1}$ Division of Plant Pathology, ${ }^{2}$ Division of Plant Pathology, Sher-e-Kashmir University of \\ Agricultural Sciences and Technology of Jammu, 180009, India \\ *Corresponding author
}

\begin{tabular}{|c|}
\hline Keywords \\
\hline $\begin{array}{l}\text { Bacillus, Damping } \\
\text { off, Penicillium } \\
\text { glaucum, Pythium, } \\
\text { Trichoderma }\end{array}$ \\
\hline Article Info \\
\hline $\begin{array}{l}\text { Accepted: } \\
\text { 16 March } 2018 \\
\text { Available Online: } \\
10 \text { April } 2018\end{array}$ \\
\hline
\end{tabular}

Keywords

Bacillus, Damping off, Penicillium glaucum, Pythium oderma

\section{Accepted:}

Available Online:

10 April 2018

\section{A B S T R A C T}

Chilli (Capsicum annuum L.) is one of the most important vegetable crop grown in India for both unripe (green) and ripe (red) fruit. Chilli crop is attacked by several diseases viz. damping-off, wilt, anthracnose, die back, root rot, bacterial wilt etc. Among the fungal diseases, damping-off caused by Pythium aphanidermatum (Edson) Fitz. in nurseries is a major constraint in chilli production causing $62 \%$ mortality of seedlings and is responsible for 90 per cent of plant death either as pre or post-emergence damping off in the nursery fields and is very common problem in fields and greenhouse, where the organism kills newly emerged seedlings. Traditionally, this disease is controlled by the application of synthetic fungicides like azoxystrobin (strobilurin), fosetyl-aluminum (alkyl phosphonate), mefenoxam and metalaxyl (acylanilide), etridiazole (triadiazole), and propamocarb (carbamate) but phytotoxicity by these fungicide residues are major problems. For this reason, a number of restrictions are imposed in the licensing, registering and using of each chemical. Development of fungicide resistance by Pythium spp. further discourages its use for disease control. Other control measures like host resistance has not yet become a viable measure. No resistant variety has yet been developed and released against these soil borne pathogens causing damping-off at seedling stage. Hence, such situations have prompted researchers to look out for alternate strategies for managing the disease. One of the key elements of such sustainable agriculture is the application of biological controlling strategies, for plant protection. Biological control has been known since 1874, when Roberts showed the suppressive activity of Penicillium glaucum against bacteria and regarded this phenomenon as antagonism. The soil has an enormous untapped potential of antagonistic microbes such as Trichoderma spp., Bacillus spp., and the fluorescent pseudomonads, which show antagonistic effects against soil borne plant pathogenic organisms such as Pythium spp.

\section{Introduction}

Chilli (Capsicum annuum L.) belongs to Solanaceae family and is a native of tropical
America. It is grown throughout the world for its green and red ripe fruits as it is a lucrative crop and forms an indispensable adjuvant almost in every house. India is one of the 
major chilli growing countries, producing 1.446 million tonnes of ripe dry chillies with an area of 0.869 million hectares (Anonymous, 2013) and has been the second largest exporter of chilli in the international market, exporting products ranging from dried form of chilli to chilli powder and oleoresins across 90 countries (Muthukumar et al., 2010). India also leads in the context of maximum area covered under chilli cultivation. Chilli fruit is used fresh, cooked, pickled and canned in sauces and as powder for hot spices (Parey et al., 2013). Nadkarni (1927) has reported many medicinal value of chilli. Its paste is externally used as rubefacient and as local stimulant for the tonsils in tonsillitis. It is irritant internally and produces gastroenteritis. It is used with many ingredients for local remedies.

Chilli crop is attacked by several diseases of biotic and abiotic nature leading to great loss to cultivators. Damping off disease is one of them that causes heavy losses to the growers. It is responsible for 90 per cent of plant death either as pre or post-emergence damping off in the nurseries and fields (Sowmini, 1961). These diseases of vegetables and field crops are considered an important limiting factor in successful cultivation of crop plants throughout the world.

\section{Etiology}

\section{Causal organism}

Most Pythium species cause seed rot and damping off ofmany crops including chilli and tomato (Shah and Burns, 1996). The genus Pythium (kingdom: Straminopila; phylum: Oomycota; class: Oomycetes; subclass: Peronosporomycetidae; order: Pythiales and family: Pythiaceae) is a complex genus containing over 200described species that occupy a variety of terrestrial and aquatic ecological habitats (Dick, 2001), perhaps the most economically important members of this genus are plant pathogens (Hendrixand Campbell, 1973), many of which have a broad host range and cause losses by both pre- and post-emergence damping off (Erwin and Ribeiro, 1996), as well as reduction in plantgrowth and yield due to root rot (Plaats-Niterink, 1981). Seeds attacked by this fungus usually fail to germinate whereas seedlings can be damaged in two ways: the roots may rot causing the seedling to wilt and die quickly, or the seedling may be attacked on the stem at the ground line, causing the seedling to collapse.

Pythium aphanidermatum (Edson) Fitz. is causal organism causing damping off of disease in chillies. $P$. aphanidermatum is cosmopolitan in distribution and one of the most common plant parasitic pathogen of a number of other crop plants in warmer parts of the world. $P$. aphanidermatum is also known to cause infection on a wide range of plant species, belonging to different families viz., Amaranthaceae, Amaryllidaceae, Araceae, Basellaceae, Bromeliaceae, Cactaceae, Chenopodiaceae, Compositae, Coniferae, Convolvulaceae, Cruciferae, Cucurbitaceae, Euphorbiaceae, Gramineae, Leguminosae, Linaceae, Malvaceae, Moraceae, Passifloraceae, Rosaceae, Solanaceae, Umbelliferae, Violaceae, Vitaceae, Zingiberaceae (Waterhouse and Waterston, 1964).

\section{Symptomology}

Damping off occurs in two stages, i.e. the preemergence and the post-emergence phase. In the pre-emergence the phase the seedlings are killed just before they reach the soil surface. The young radical and the plumuleare killed and there is complete rotting of the seedlings. The post-emergence phase is characterized by the infection of the young, juvenile tissues of the collar at the ground level. The infected 
tissues become soft and water soaked. The seedlings topple over or collapse (Agrios, 2005).

\section{Predisposition}

The disease is soil borne in nature and practice of monoculture together make the crop prone to disease. The cultivars grown are not resistant to the pathogen which also helps to spread the disease. P.aphanidermatum is an aggressive pathogen at high temperature (Gold and Stanghellini, 1985).

\section{Perpetuation of pathogen}

Many Pythium species are known to be important soil borne plant pathogens (Hendrix and Campbell, 1973). These species are most commonly identified as causal agents of preand post-emergence damping-off, leading to poor stands and low crop vigor (Agrios, 2005). Some Pythium species can infect mature plants, causing significant damage to yields, such as the species that cause carrot cavity spot (Suffert and Guibert, 2007). Pythium species survive in the soil via oospores or sporangia (Hendrix and Campbell, 1973; Plaats-Niterink, 1981). The oospore, a sexual spore, is the primary survival structure of many Pythium species because of the thick-wall enables the spore to survive in the absence of a host, even in the presence of unfavorable soil conditions (Dick, 1990). The sporangia and hyphal swellings of Pythium, on the other hand, serve as the asexual reproductive structures for many of species (Hendrix and Campbell, 1973; PlaatsNiterink, 1981).

\section{Management}

\section{Cultural methods}

Cultural management practices are the primary strategies used to address disease problems (Sullivan, 2004). Site selection, such as choosing land without history of soil borne diseases, and planting in fields with well-drained soil, is important for preventing damping-off (Koike et al., 2000). Abawi and Widmer (2000) reviewed the impact of some cultural practices on soil health management practices in controlling soil borne pathogens and concluded that the cultural practices such as cover cropping and green manure incorporation, use of composts, crop rotation, and tillage practices improve soil compaction, increase drainage, and increase soil temperature, all of which have an impact on the physical soil characteristics as well as increasing diversity of the soil biota and ultimately reducing the pathogen inoculum.

The use of resistant cultivars can be the most important weapon for damping off disease control. However desirable cultivars with resistance to important soil borne diseases are not always available (Koike et al., 2000).

\section{Chemical management}

Management of soil borne pathogens has been attempted by many workers/researchers by manipulation of cultural practices and chemicals. However, according to Haware and Kannaiyan (1992) the management of seed borne and soil borne diseases has always been problematic. Satija and Hooda (1987) evaluated fungicides belonging to different chemical groups for their efficacy in controlling damping-off tomato and chili caused by Fusarium solani and Pythium aphanidermatum. As seed treatment, copper oxychloride was found best fungicide in controlling damping-off of the both the tests plants caused by $F$. solani whereas for the control of damping-off due to $P$. aphanidermatum MEMC was found the best fungicide. However, for controlling dampingoff caused by both the fungi MEMC and captan were very promising on tomato and 
captafol on chill. Bucherau et al., (1981) obtained good control of pre-emergence damping off with Ridomil (metalaxyl) caused by $P$. ultimumin alfafa. Efficacy of Ridomil (metalaxyl) has been confirmed as seed dresser against $P$. ultimumin case of carrot, chick pea, cotton, cucumber, pea and sugar beet significantly superior in reducing the seed rot percentage (Kaiser and Hanan, 1983; Rama, 1980). Ayub et al., (1998) reported that Ridomil (metalaxyl) at all concentrations effectively controlled the damping off disease in tomato. Abdel Rahim and Abu Surrieh (1991) tested 9 fungicides such as Bavistin, Benlate, Topsin M, Miltox special, Dithane M-45, Dithane S-60, Ridomil MZ, Rovral and Captan 50 against damping off of cucumber and found Ridomil MZ best among them in preventing the disease. Hickman and Michailides (1998) reported that fallow field soil, solarized soil, methyl bromide treated soil and metalaxyl soil drench treatments were all effective against damping off caused by $P$. aphanidermatum of cucumber.

Although fungicides have shown promising results in controlling the damping-off disease, phytotoxicity and fungicide residues are major problems leading to environmental pollution and human health hazards. For this reason, a number of restrictions are imposed in the licensing, registering and using of each chemical (Cuthbertson et al., 2010). Hence use of environmental friendly bio-control agents can more effectively control the soil borne phyto-pathogens (Nam et al., 1988 and Saleem et al., 2000).

\section{Biological management}

Biological control of soil borne plant pathogens has received tremendous attention on global level on account of the growing public concern about health hazardous and pollutant effects of the pesticides (Ooijkass et al., 1998). Plant ecosystem bestowed with a number of microorganisms, acts as competitors or antagonists to pathogens and act as viable and potent alternative to plant conventional chemicals for the management of plant diseases (Jeyarajan and Angappan, 1998). In sustainable agriculture, biological control assumes major importance especially, where soil borne diseases are serious (Harman, 2006). Various biocontrol agents have been tried against different species of Pythium and got considerable results.

Growth inhibition of the phytopathogens by the Trichoderma metabolites has been well researched (Dennis and Webster, 1971). Successful management of damping-off caused by Pythium species in various crops by application of Trichoderma has been previously reported (Jayaraj et al., 2006). Gomathi et al., (2011) evaluated the antibiotic ability of local isolates of Trichoderma spp. against damping off disease. Trichoderma spp. showed maximum activity in controlling the disease with influence on soil physicochemical parameters. Hanson (2003) evaluated various isolates of Trichoderma virens and found almost all isolates effective against damping off of sugarbeet seedlings caused by Rhizoctonia solani in the greenhouse and also found peroxidase activity significantly higher in roots of plants treated with biocontrol effective strain. Subash et al., (2013) evaluated $T$. harzianum against damping off disease caused by Fusarium oxysporium, Rhizoctonia solani and Alternaria alternata and found T. harzianum efficient not only to inhibit the growth of all the above pathogens but also to enhance the growth of the plants.

One of the mechanisms observed to be adopted by Trichoderma species to parasitize pathogenic organisms is by competition. Trichoderma suppress the growth of these phytopathogenic fungus through the over growth. On this basis the twelve isolates of 
Trichoderma were evaluated by Arunachalam \& Sharma (2012). All the T. harzianum isolates were found to be more profuse than $T$. viride isolates with isolate Th3 having the maximum effect in inhibiting the growth of $P$. aphanidermatum (86.4\%).

In addition, several studies have reported the use of bacteria and actinomycetes (ElTarabily et al., 2009). Bacterial strains of Pseudomonas fluorescens and other species are the most commonly reported fluorescent pseudomonads used to suppress damping-off (Martin and Loper, 1999). Carisse et al., (2003) reported efficient control of Pythium damping off using Bacillus marinus, $P$. fluorescens and P. aeruginosa. Pseudomonas antagonists were found to be superior to Bacillus antagonists in the control of damping-off of cucumber and sugar beet (Georgakopoulos et al., 2002). Other studies reported successful use of pseudomonads as biocontrol agents in greenhouses (Rankin and Paulitz, 1994) and fields (Weller and Cook, 1986). In addition, Pseudomonas species were used successfully to control several diseases in crops other than cucumber (Amein et al., 2008). Pseudomonas fluorescens (Elad and Chet, 1987) and native isolates have been successfully used for the biocontrol of damping-off disease. Ardakani et al., (2010) found $P$. fluorescens strains more effective than the common seed dressing fungicides (Carboxin/Thiram) for controlling damping off of cotton under greenhouse conditions. Several other studies reported antagonistic activity among Pseudomonas species including $P$. fluorescens and $P$. corrugate against Pythium species (Hultberg et al., 2000). Pseudomonas spp. in combination with other biocontrol agents or applied singly have been tested for their biocontrol potential against many diseases as well as for the damping off of chilli (Jain et al., 2012; Muthukumar et al., 2010). Kumar et al., (2010) observed increase in yield parameters viz., shoot length, fruit number and biomass production in chilli with Pseudomonas fluorescens combined with other antagonists.

The mycoparasitic potential of Pseudomonas spp. is well documented by earlier workers (Anitha and Tripathi, 2001). Fluorescent pseudomonads not only colonize the root system but they also produce a variety of antagonistic secondary metabolites that include siderophores, antibiotics and volatile compounds such as cyanide (Fravel, 1988; Kloepper et al., 1980). Several cell wall degrading enzymes such as chitinase and $\hat{a}-1$, 3-glucanase are involved in this process and they are capable of degrading chitin and $\hat{a}-$ 1,3-glucan respectively, the major components of fungal cell walls (Bhowmik et al., 2002).

Bacillus has shown promising results for the biological control of various plant pathogens as well as growth promoters of some crops (Podile and Laxmi, 1998). Kumaresanet al., (2005) reported significant decrease in the damping off disease caused by $P$. aphanidermatumby treatment with the $B$. subtilis with increase in the shoot length and root length respectively. Bacillus subtilis Cohn has been successfully used for control of diseases caused by Pythium, Rhizoctonia, Gaeumannomyces, Sclerotinia, Fusarium and others (Schmiedeknecht et al., 1998; Ryder et al., 1999; Bacon et al., 2001).

The antagonistic activities of $B$. subtilisare mainly attributed to the production of antibiotic substances, most of which are dipeptides or cyclic peptides (Loeffler et al., 1990). The bacterium is also capable of producing certain volatile extra-cellular metabolites that have antifungal activity (Podile and Prakash, 1996). B. subtilis is also a well-known producer of hydrolytic enzymes, including cellulase, chitinase and b1,3-glucanase (Marten et al., 2000), which 
causes lysis of fungal cell walls and membranes. In addition to direct antagonistic activity against several soil borne fungal pathogens, B. subtilisis known to promote plant growth and yield (Krebs et al., 1998). There is also emerging evidence indicating that the bacterium could be involved in induction of systemic acquired resistance in plants (Podile and Laxmi, 1998; Ghonim, 1999; Collins and Jacobson, 2003).

It has been reported that application of a single strain of a biological control agent is less effective than chemical protection and its effect may not be consistence (Weller, 1998). This low and unstable efficacy or variability of plant protection of biological control agents may be due to the complexity of the ecosystem (Guetsky et al., 2002). Possible approaches of enhancement of the efficacy of biological control agent against soil borne pathogens has been reviewed and it has been identified that one way to improve the biological control ability may be the use of mixtures or combinations of biocontrol agents (Spadaro and Gullino, 2005). Pierson and Weller (1994) reported that combining different Pseudomonas fluorescens strains increased the control of wheat take when compared to other strains used singly. Raupach and Kloepper (1998) showed that the use of combined applications of bacterial biocontrol agents increased plant protection against the cucumber pathogens significantly. Apart from the bacterial combinations, some reports indicated the combination of bacterial bio-agent with Trichoderma spp. showed increased plant protection than they showed when used single. Brewer and Larkin (2005) reported that combination of Bacillus subtilis and Trichoderma virens enhanced resistance against $R$. solani on potato than these biocontrol agents when used singly. A positive probably synergistic interaction between Trichoderma spp. strains and bacterial strains has been reported for combined applications in controlling plant pathogens (Fogliano et al., 2002). Sudharani et al., (2014) reported a positive interaction between PGPR's and fungal bio-agents with increased seedling vigour and root and shoot biomass. The combination, $T$ harzianum $($ TR20) $+P$. fluorescens (P28), was found most effective in reducing disease incidence (66.7\%) than the control (Rini and Sulochana, 2006). Highest per plant yield was also recorded in the treatment combination TR20+P28.

Chilli (Capsicum annuum L.) both unripe (green) and ripe (red) fruit, is one of the most important vegetable crop grown in India as an indispensable condiment, digestive stimulant and a colouring agent. Besides pungency due to Capsaicin and vitamins such as vitamin A and $\mathrm{C}$, the green fruit is also known to contain vitamin $\mathrm{P}$ (rutin) in appreciable proportion.

Chilli crop is attacked by several diseases viz. damping-off, wilt, anthracnose, die back, root rot, bacterial wilt etc. Among the fungal diseases, damping-off caused by Pythium aphanidermatum (Edson) Fitz. in nurseries is a major constraint in chilli production and is responsible for 90 per cent of plant death either as pre or post-emergence damping off.

Traditionally, this disease is controlled by the application of synthetic fungicidesbelonging to different classes of chemicals including azoxystrobin (strobilurin), fosetyl-aluminum (alkyl phosphonate), mefenoxam and metalaxyl (acylanilide), etridiazole (triadiazole), and propamocarb (carbamate).

Although these fungicides have shown promising results in controlling the dampingoff disease but phytotoxicity by fungicide residues are major problems leading to environmental pollution and human health hazards such as adverse genetic effects, causing morphological and physiological 
abnormalities in test animals. Development of fungicide resistance by Pythium spp. further discourages its use for disease control.

Other control measures as host resistance have not yet become a viable measure.

Hence, such situations have prompted researchers to look out for alternate strategies for managing the disease.

One of the key elements of such sustainable agriculture is the application of biological controlling strategies, for plant protection.

\section{References}

Abawi, G.S. and Widmer, T.L. 2000. Impact of soil management practices on soil borne pathogens, nematodes, and root diseases of vegetable crops. Applied Soil Ecology15:37-47.

Abdel Rahim, A.M. and Abu Surrieh, A.A. 1991. Chemical control of Pythium debaryanum, the causal organism of damping off in cucumber. Arab Journal of Plant Protection9: 14-18.

Agrios, G.N. 2005. Plant Pathology, Fifth Edition. Academic Press, Inc., San Diego, CA.

Amein, T., Omer, Z. and Welch, C. 2008. Application and evaluation of Pseudomonas strains for biocontrol of wheat seedling blight. Crop Protection 27: 532-536.

Anitha, K. and Tripathi, N.N. 2001. Laboratory screening of fungal and bacterial antagonists against Rhizoctonia solani khun. And Pythium aphanidermatum (Edson) Fitz. inciting seedling diseases of okra. Indian Journal of Plant Protection 29: 46-148

Anonymous, 2013. Production and area under chillies and peppers dry in India for the year 2011.Food and Agriculture Organization (FAO), Rome.
Ardakani, S.S., Heydari, A., Khorasani, N. and Arjmandi, R. 2010. Development of new bioformulations of Pseudomonas fluorescens and evaluation of these products against damping-off of cotton seedlings. Journal of Plant Pathology92: 83-88.

Arunachalam, M.K. and Sharma, P. 2012. Confrontation assay for Trichoderma as a potential biocontrol agent against Pythium aphanidermatum and Sclerotiniasclerotiorum. India Pest Management in Horticultural Ecosystems 18:74-77

Ayub, M., Khan, A. and Amin, M. 1998. Efficacy of some of the fungicides for managing pre-emergence damping off in tomato and their effect on seedlings vigour. Sarhad Journal of Agriculture 14: 475-481.

Bacon, C.W., Yates, I.E., Hinton, D.M. and Meredith. F. 2001. Biological control of Fusarium moniliforme in maize. Environmental Health Perspective 109(Suppl.): 325-332.

Bhowmik B., Singh, R.P., Jayaraman, J. and Verma, J.P. 2002. Population dynamics of cotton endophytic Pseudomonas their antagonism and protective action against the major pathogens of cotton. Indian Phytopathology 55: 124-132.

Brewer, M.T. and Larkin, R.P. 2005. Efficacy of several potential biocontrol organisms against Rhizoctonia solani on potato. Crop Protection 24:939-950.

Bucherau, G.W., Vigil, F.R., Mankin, C.J. and Writh, C.W. 1981. Control of alfafa damping off with seed treatment. Phytopathology 71: 205.

Carisse, O., Bernier, J. and Benhamou, N. 2003. Selection of biological agents from composts for control of dampingoff of cucumber caused by Pythium ultimum. Canadian Journal of Plant Pathology 25: 258-267. 
Collins, D.P. and Jacobsen, B. 2003. Optimizing a Bacillus subtilis isolate for biological control of sugar beet Cercospora leaf spot. Biological Control 26:153-161.

Cuthbertson, A.G.S., Blackburn, L.F., Northing, P., Luo, W., Cannon, R.J.C. and Walters, K.F.A. 2010. Chemical compatibility testing of the entomopathogenic fungus Lecanicillium muscarium to control Bemisia tabaci in glasshouse environment. International Journal of Environmental Science Technology7: 405-409.

Dennis, C. and Webster, J. 1971. Antagonistic Properties of Species Groups of Trichoderma. I. Production of Nonvolatile Antibiotics. Transactions of the British Mycological Society 57: 25-39.

Dick, M.W. 1990. Keys to Pythium. Department of Botany, School of Plant Sciences, University of Reading, Reading, U.K.

Dick, M.W. 2001. The Peronosporomyletes. In: The Mycota VII part A. Systematics Evolution. [Eds. D.J. McLaughlin, E.G. McLaughlin and P.A. Lemke]. Springer Verlag, Berlin, pp. 39-72.

Elad, Y. and Chet, I. 1987. Possible role of competition for nutrient in biocontrol of Pythium damping-off by bacteria. Phytopathology77: 190-195.

El-Tarabily K.A., Nassar A.H., Hardy G.E. and Sivasithamparam K. 2009. Plant growth promotion and biological control of Pythium aphanidermatum, a pathogen of cucumber, by endophytic actinomycetes. Journal of Applied Microbiology106: 13-26.

Erwin, D.C. and Ribeiro, O.K. 1996. Phytophthora Diseases worldwide. The American Phytopathological Society, St Paul, MN.

Fogliano, V., Ballio, A., Gallo, M., Woo, S., Scala, F. and Lorito, M. 2002. Pseudomonas lipopeptides and fungal cell wall degrading enzymes act synergistically in biological control. Molecular Plant Microbe Interactions 15: 323-333

Fravel, D.R. 1988. Role of antibiosis in the biocontrol of plant diseases. Annual Review of Phytopathology 26:75-91.

Georgakopoulos, D.G., Fiddaman, P., Leifert, C. and Malathrakis, N.E. 2002. Biological control of cucumber and sugarbeet damping off caused by Pythium ultimum with bacterial and fungal antagonists. Journal of Applied Microbiology 92: 1078-1086.

Ghonim, M.I. 1999. Induction of systemic resistance against Fusarium wilt in tomato with the biocontrol agent Bacillus subtilis. Bulletin of Faculty of Agriculture, University of Cairo 50: 313-328.

Gold, S.E. and Stanghellini, M.E. 1985. Effects of temperature on Pythium root rot of spinach Spinaciaoleracea grown under hydroponic conditions. Phytopathology 75: 333-337.

Gomathi, S., Ambikapathy, V. and Pannerselvam, A. 2011. Potential strain of Trichoderma spp. to control damping-off of disease in chilli. International Journal of Applied Biology and Pharmaceutical Technology 2: 64-69.

Guetsky, R., Shtienberg, D., Elad, Y., Fischer, E. and Dinoor, A. 2002. Improving biological control by combining biocontrol agents each with several mechanisms of disease suppression. Phytopathology 92: 976-985.

Hanson, L.E. 2003. Poster presentation. $1^{\text {st }}$ joint IIRB-ASSBT Congress, $26^{\text {th }}$ Feb.$1^{\text {st }}$ March 2003, San Antonio (USA).

Harman, G.E. 2006. Overview of mechanisms and uses of Trichoderma spp. Phytopathology 96: 190-194.

Haware, M.P. and Kannaiyan, J. 1992. Seed transmission of Fusarium udum in 
pigeonpea and its control by seed treatment fungicides. Seed Science Technology 20: 597-601.

Hendrix, F.F. and Campbell, W. 1973. Pythium as plant pathogens. Annual Review of Phytopathology 11: 78-98.

Hickman, G.W. and T. J. Michailides. Control options for greenhouse cucumber damping-off disease. Journal of Vegetable Crop Production 4: 45-48.

Hultberg, M., Alsanius, B. and Sundin P. 2000. In vivo and In vitro interaction between Pseudomonas fluorescens and Pythium ultimumin the suppression of damping-off in tomato seedlings. Biological Control 19: 1-8.

Jain, A., Singh, S., Sarma, B.K. and Singh, H.B. 2012. Microbial consortium mediated reprogramming of defence network in pea to enhance tolerance against Sclerotiniasclerotiorum. Journal of Applied Microbiology 112: 537-550.

Jayaraj, J., Radhakrishnan, N.V. and Velazhahan, R. 2006. Development of formulations of Trichoderma harzianum strain M1 for control of damping-off of tomato caused by Pythium aphanidermatum. Archives of Phytopathology and Plant Protection 39: 1-8.

Jeyarajan, R. and Angappan, K. 1998. Mass production technology for fungal antagonists and field evaluation, pp 4858. In: Biological Control of Plant Diseases, Phytoparasitic nematodes and weeds (Eds. S.P. Singh and S.S. Hussaini). Project Directorate of Biological Control, Bangalore, Karnataka, India.

Kaiser, W.J. and Hannan, R.M. 1983. Etiology and control of seed decay and pre-emergence damping off of chickpea by Pythium ultimum. Plant Disease 67: 77-81.

Kloepper, J.W., Leong, J., Tientze, M. and Schroth, M.N. 1980. Enhanced plant growth by siderophores produced by plant growth promoting rhizobacteria. Nature 286:885-886.

Koike, S.T., Gaskell, M., Fouche, C., Smith, R. and Mitchell, J. 2000. Plant disease management for organic crops. ANR Publication 7252, University of California, Davis, CA.

Krebs, B., Hoding, B., Kubart, S., Workie, M.A., Junge, H., Schmiedeknecht, G., Grosch, R., Bochow, W. and Hevesi, M. 1998. Use of Bacillus subtilis as biocontrol agent. I. Activities and characterization of Bacillus subtilis strains. Journal of Plant Diseases and Protection 105: 181-197.

Kumar, R., Hooda, I. and Karwasra, S.S. 2010. Efficacy of mahapanchagavya (mpg) in controlling damping-off in tomato caused by Pythium aphanidermatum. Bangladesh Journal of Agricultural Research 35: 11-16.

Kumaresan, K., Subramanian, M., Vaithiyanathan, S., Sevagaperumal, N. and Gopal, C. 2005. Development of bioformulations of antagonistic bacteria for the management of damping off of Chilli (Capsicum annuum L.). Archives of Phytopathology and Plant Protection 38: 19-30.

Loeffler, W., Katzer, W., Kremer, S., Kugler, M., Petersen, F., Jung, G., Rapp, C. and Tschen, J.S.M. 1990. Gegen Pilze wirksame Antibiotika der Bacillus subtilis-GB 03-Gruppe. Forum Mikrobiology3:156-163.

Marten, P., Smalla, K. and Berg, G. 2000. Genotypic and phenotypic differentiation of an antifungal biocontrol strain belonging to Bacillus subtilis. Journal of Applied Microbiology89:463-471.

Martin, F.N. and Loper, J.E. 1999. Soil borne plant diseases caused by Pythium spp.: Ecology, epidemiology, and prospects 
for biological control. Critical Review of Plant Sciences 18:111-181.

Muthukumar, A., Eswarana, A., Nakkeeranb, S. and Sangeethaa, G. 2010. Efficacy of plant extracts and biocontrol agents against Pythium aphanidermatum inciting chilli damping-off. Crop Protection29: 1483-1488.

Nadkarni, K.M. 1927. The Indian MateriaMedica. Bombay. p xviii -1142 .

Nam, C.G., Jee, H.J. and Kim, C.H. 1988. Studies on biological control of Phytophthora blight of red pepper. Korean Journal of Plant Pathology4: 313-318.

Ooijkaas, L.P., Thamper, J. and Biutelaar, R.M. 1998. Biomass estimation of Coniothyrium minitaus in solid state fermentation. Enzyme Microbiological Technology 26: 355-361

Parey, M.A., Razdan, V.K. and Sofi, T.A. 2013. Comparative study of different fungi associated with fruit rot of chilli and screening of chilli germplasm against Colletotrichum capsici. International Journal of Agriculture and Crop Sciences 5: 723-730.

Pierson, E.A. and Weller, D.M. 1994. Use of mixtures of fluorescens pseudomonads to suppress take-all and improve the growth of wheat. Phytopathology84: 940-947

Plaats-Niterink, A.J.V. 1981. Monograph of the genus Pythium. Studies in Mycology21: 1-242.

Podile, A.R. and Laxmi, V.D.V. 1998. Seed bacterization with Bacillus subtilis AF1 increases phenylalanine ammnonialyase and reduces the incidence of fusarial wilt in pigeonpea. Journal of Phytopathology, 146: 255-259.

Podile, A.R. and Prakash, A.P. 1996. Lysis and biological control of Aspergillus niger by Bacillus subtilis AF 1 . Canadian Journal of Microbiology, 42:533-538.
Raaijmakers, J.M., Van Oorschot, M.M.P., Van der Sluis, I., Schippers, B. and Bakker, P.A.H.M. 1995. Dose response relationship in biological control of Fusarium wilt of radish by Pseudomonas sp.Phytopathology85: 1075-1081.

Rama, H. 1980. Chemical control of seedling diseases of sugar beet caused by sclerotiumrolfsii and Pythium aphanidermatum. Indian Phytopathology 33: 145.

Rankin, L. and Paulitz, T.C. 1994. Evaluation of rhizosphere bacteria for biological control of Pythium root rot of greenhouse cucumbers in hydroponic culture. Plant Disease 78: 447-451.

Raupach, G.S. and Kloepper, J.W. 1998. Mixtures of plant growth promoting rhizobacteria enhance biological control of multiple cucumber pathogens. Phytopathology 88: 1158-1164.

Rini, C.R. and Sulochana, K.K. 2006. Management of seedling rot of chilli (Capsicum annum L.) using Trichoderma sp. and fluorescent pseudomonads (Pseudomonas fluorescens). Journal of Tropical Agriculture 44: 79-82.

Ryder, M.H., Zhinong, Y., Terrace, T.E., Rovira, R. D., Wenhua, T., Carrell, R.L., Yan, Z. and Tang, W. 1999. Use of strains of Bacillus isolated in China to suppress take-all and Rhizoctonia root rot, and promote seedling growth of glasshouse-grown wheat in Australian soils. Soil Biology and Biochemistry, 31: 19-29.

Saleem, A., Hamid, K., Tariq, A.H. and Jamil, F.F. 2000. Chemical control of root and collar rot of chillies. Pakistan Journal of Phytopathology, 12: 1-5.

Satija, D.V. and Hooda, I. 1987. Influence of farmyard manure in the efficacy of fungicides in controlling damping-off of 
tomato and chilli. Vegetable science 14:58-64.

Schmiedeknecht, G., Bochow, H. and Junge, H. 1998. Use of Bacillus subtilis as biocontrol agent. II. Biological control of potato diseases. Journal of Plant Diseases and Protection 105: 41-48.

Shah, S.D.A. and Burns, R.G. 1996. Biological Control of Pythium Damping-off of sugar beet by Pseudomonas putida applied to seed pellets. Plant Pathology 45: 572-582.

Sowmini, R. 1961. Studies on phycomycetes in agricultural soils with special reference to Pythiaceae. M.Sc. (Agri.) Thesis, University of Madras, pp. 160.

Spadaro, D. and Gullino, M. L. 2005. Improving the efficacy of biocontrol agents against soil borne pathogens. Crop Protection 24: 601-613.

Subash, N., Meenakshisundaram, M., Unnamalai, N. and Sasikumar, C. 2013. Effect of Trichoderma harzianum to control damping-off disease and growth promotion in chilli (Capsicum annuum). International Journal of Pharma and Bio Sciences 4: 1076-1082.

Sudharani, M., Shivaprakash, M.K. and Prabhavathi, M.K. 2014. Role of consortia of biocontrol agents and PGPR $s$ in the production of cabbage under nursery condition. International Journal of Current Microbiology and Applied Sciences 3: 1055-1064.

Suffert, F. and Guibert, M. 2007. The ecology of a Pythium community in relation to the epidemiology of carrot spot. Applied Soil Ecology 35: 488-501.

Sullivan, P. 2004. Sustainable management of soil- borne plant diseases. ATTRA, National Sustainable Agriculture Information Service, California, U.S.A.

Waterhouse, G.M. and G.M. Waterston. 1964. Pythium aphanidermatum. [Descriptions of Fungi and Bacteria].CAB International. 4: Sheet 36.

Weller, D. M. 1998. Biological control of soil borne pathogens in the rhizosphere with bacteria. Annual Review of Phytopathology 26: 379-407

Weller, D.M. and Cook, R.J. 1986. Increased growth of wheat by seed treatments with fluorescent pseudomonads and implications of Pythium control. Canadian Journal of Plant Pathology 8: 328-334.

\section{How to cite this article:}

Misba Majeed, G. Hassan Mir, Mudasir Hassan, Fayaz A. Mohuiddin, Shazia Paswal and Saima Farooq. 2018. Damping Off in Chilli and Its Biological Management-A Review. Int.J.Curr.Microbiol.App.Sci. 7(04): 2175-2185. doi: https://doi.org/10.20546/ijcmas.2018.704.247 